\title{
Not just the usual suspects: Insect herbivore populations and communities are associated with multiple plant nutrients
}

\author{
Anthony Joern, ${ }^{1,4}$ Tony Provin, ${ }^{2}$ and Spencer T. Behmer ${ }^{3}$ \\ ${ }^{1}$ Division of Biology, Kansas State University, Manhattan, Kansas 66506 USA \\ ${ }^{2}$ Department of Soil and Crop Sciences, Texas A\&M University, College Station, Texas 77843 USA \\ ${ }^{3}$ Department of Entomology, Texas A\&M University, College Station, Texas 77843 USA
}

\begin{abstract}
The relationship between plant nutrient content and insect herbivore populations and community structure has long interested ecologists. Insect herbivores require multiple nutrients, but ecologists have focused mostly on nitrogen (an estimate of plant protein content), and more recently phosphorus $(\mathrm{P})$; other nutrients have received little attention. Here we document nutrient variation in grass and forb samples from grassland habitats in central Nebraska using an elemental approach; in total we measured foliar concentrations of 12 elements ( $\mathrm{N}$ and $\mathrm{P}$, plus $\mathrm{S}, \mathrm{B}, \mathrm{Ca}, \mathrm{Mg}, \mathrm{Na}, \mathrm{K}, \mathrm{Zn}, \mathrm{Fe}, \mathrm{Mn}$, and $\mathrm{Cu}$ ). We detected significant variability among sites for $\mathrm{N}, \mathrm{P}, \mathrm{Mg}, \mathrm{Na}, \mathrm{K}$, and $\mathrm{Cu}$. We next used a model selection approach to explore how this nutritional variation and plant biomass correlate with grasshopper densities (collectively and at the feeding-guild level), and principal component analysis to explore nutrient correlations with grasshopper community species composition. When all grasshoppers were pooled, densities varied among sites, but only P was associated with abundance of the elements shown to vary between sites. Different responses occurred at the feeding-guild level. For grass specialists, densities were associated with N, plus $\mathrm{P}, \mathrm{Mg}$, and $\mathrm{Na}$. For forb specialists, $\mathrm{N}$ and $\mathrm{P}$ were often associated with density, but associations with $\mathrm{Na}$ and $\mathrm{K}$ were also observed. Finally, mixed-feeder abundance was strongly associated with biomass, and to a lesser extent $\mathrm{P}, \mathrm{Mg}, \mathrm{Na}$, and $\mathrm{Cu}$. At the community level, $\mathrm{B}$, $\mathrm{Ca}, \mathrm{Zn}$, and $\mathrm{Cu}$, plus biomass, explained $>30 \%$ of species composition variation. Our results confirm the positive association of $\mathrm{N}$ and $\mathrm{P}$ with insect herbivore populations, while suggesting a potential role for $\mathrm{Mg}, \mathrm{Na}$, and $\mathrm{K}$. They also demonstrate the importance of exploring effects at the feeding-guild level. We hope our data motivate ecologists to think beyond $\mathrm{N}$ and $\mathrm{P}$ when considering plant nutrient effects on insect herbivores, and make a call for studies to examine functional responses of insect herbivores to dietary manipulation of $\mathrm{Mg}, \mathrm{Na}$, and $\mathrm{K}$. Finally, our results demonstrate correlations between variation in nutrients and species assemblages, but factors not linked to plant nutrient quality or biomass likely explain most of the observed variation.
\end{abstract}

Key words: Acrididae; grasshoppers; insect herbivory; mixed grass prairie; Nebraska sandhills grassland (USA); nutritional ecology; Orthoptera; physiological ecology.

\section{INTRODUCTION}

The distributions and abundances of insect herbivores are notoriously heterogeneous in time and space at multiple spatial scales (Barbosa and Schultz 1987, Cappuccino and Price 1995). Two factors that can be linked with these patterns are plant nutritional quality and biomass. Exploring the relationship between plant biomass and insect herbivores is relatively straightforward, in part because these two factors are easily quantified. In contrast, linking plant quality with insect herbivore abundance is a greater challenge. First, because insect herbivores require multiple nutrients and perform best when they acquire nutrients in a

Manuscript received 26 June 2011; revised 10 November 2011; accepted 17 November 2011. Corresponding Editor: S. J. Simpson.

${ }^{4}$ E-mail: ajoern@ksu.edu specific blend, both in terms of amounts and ratios (Behmer and Joern 2008, Behmer 2009, Raubenheimer et al. 2009), there are inherent shortcomings in reducing plant quality to a single variable (e.g., total protein or nitrogen). Second, characterizing plant quality is not straightforward because the multiple nutrients that insect herbivores require come packaged in different forms. For example, some nutrients exist as biomolecules, including amino acids (either free, or in protein), digestible carbohydrates (e.g., simple sugars and starch), fatty acids, sterols, vitamins (both fat- and watersoluble), lipogenic compounds (e.g., myo-inositol and choline), absorbic acid, and nucleic acids (Chapman 1998). Nutrients can also exist as free ions (e.g., $\mathrm{PO}_{4}{ }^{3-}$, $\mathrm{Na}^{+}, \mathrm{K}^{+}, \mathrm{Ca}^{2+}, \mathrm{Mg}^{2+}, \mathrm{Cl}^{-}, \mathrm{Fe}^{2+}, \mathrm{Zn}^{2+}$, and $\mathrm{Mn}^{2+}$ ), and are sometimes found in more complex organic structures, including enzymes and coenzymes.

The diversity of nutrient forms means that documenting and quantifying variation in plant quality can be an 
arduous task, and is not generally tractable in field studies. A methodologically more straightforward approach is to characterize plant quality at an elemental level. Carbon $(\mathrm{C})$, nitrogen $(\mathrm{N})$, and phosphorus $(\mathrm{P})$ have been the most frequently examined elements because of their importance in major classes of biological molecules (e.g., protein [C, N], carbohydrates $[\mathrm{C}]$, lipids [C], nucleic acids $[\mathrm{C}, \mathrm{N}, \mathrm{P}]$, and energetic nucleotides $[\mathrm{C}, \mathrm{N}, \mathrm{P}]$ ), and because of their critical structural roles and relatively high concentrations in organisms (Sterner and Elser 2002). However, insect herbivores require multiple nutrients, many of which contain elements other than $\mathrm{C}, \mathrm{N}$, or P. For instance, we currently know little about how other nutrient-linked elements might be associated with insect herbivore population- and community-level processes, particularly elements that occur in plants as free ions, and which serve important physiological and maintenance functions (e.g., $\mathrm{Na}, \mathrm{K}, \mathrm{Ca}, \mathrm{Mg}$ ), or structural purposes (e.g., Fe, Zn, Mn; Cribb et al. 2008).

However, because insect herbivores use nutrients in various forms, it is reasonable to question the value of characterizing plant quality using an elemental approach. The usefulness of elements as surrogates for nutrients depends on the extent to which a particular element is correlated with key nutrient biomolecules or ions. Take, for example, the relationship between nitrogen and plant protein content. Plant proteins, especially RuBisCo, are easily the greatest source of $\mathrm{N}$ in plants (Feller et al. 2008). But because the average Ncontent of the 20 amino acids found in proteins is consistently $\sim 17 \%$ (Sterner and Elser 2002), plant Ncontent shows a strong relationship with plant protein content (values of plant total protein and $\mathrm{N}$-content generally range from $5 \%$ to $30 \%$ and $0.5 \%$ to $5 \%$, respectively, depending on the plant species, its age, and its growing conditions (Schoonhoven et al. 2005)).

What about phosphorus? After uptake by plants (mainly as $\mathrm{H}_{2} \mathrm{PO}_{4}{ }^{-}$), two things can happen to $\mathrm{P}$ (Marschner 1995): (1) it can remain as inorganic phosphate $\left(\mathrm{P}_{\mathrm{i}}\right)$, or $(2)$ it is can be esterified to a carbon chain as a simple phosphate ester (e.g., sugar phosphate), or attached to another phosphate (e.g., ADP or ATP). When soil phosphorus supply is sufficient, nucleic acids (DNA, mRNA, tRNA, rRNA) are the major Pcontaining fraction, averaging $\sim 34 \%$ of the total $\mathrm{P}$ content (Kakie 1969); the remaining P-containing fractions include lipids $(\sim 21 \%)$, esters $(\sim 23 \%)$, and inorganic phosphorus $(\sim 21 \%)$. Each of these forms of $\mathrm{P}$ is available to insect herbivores (Woods et al. 2002, Perkins et al. 2004), so elemental P levels in plants correlate with $\mathrm{P}$ that can be used by insect herbivores. Interestingly, when soil $\mathrm{P}$ levels increase above sufficiency, inorganic $\mathrm{P}$ levels increase (stored in the vacuoles), but the amounts of the other P-containing fractions remain constant (Kakie 1969). With the important exception of carbon (C), which is found in all macromolecules and is particularly high in structural compounds (e.g., cellulose, lignin) that insect herbivores cannot digest (Chapman 1998), there is a strong correlation between plant elemental levels (e.g., S, Ca, $\mathrm{Na}, \mathrm{K}$, to name a few) and the availability of nutrients in this form to insect herbivores (Marschner 1995). Hence, an elemental analysis is not useful for assessing digestible carbohydrates and lipids, both of which are key components of food nutritional quality.

In the current study we use an elemental approach to broadly document natural variation in aspects of plant quality; in total we measure 12 elements $(\mathrm{N}$ and $\mathrm{P}$, plus $\mathrm{S}, \mathrm{B}, \mathrm{Ca}, \mathrm{Mg}, \mathrm{Na}, \mathrm{K}, \mathrm{Zn}, \mathrm{Fe}, \mathrm{Mn}$, and $\mathrm{Cu}$ ). We then use a model selection approach to identify correlations between variation in plant foliar elements and insect herbivore abundance, and principal component analyses to examine how variation in plant foliar elements can inform community species composition. We target grasshoppers for study for three reasons. First, they are ubiquitous insect herbivores in grasslands worldwide, with representatives from three feeding guilds in most habitats: grass-feeders, forb-feeders, and mixedfeeders (Joern 1979, Chapman and Sword 1997). Second, grasshopper population densities fluctuate greatly in time or space, and communities vary in species composition at both local and regional scales (Joern and Gaines 1990, Lockwood 1997, Jonas and Joern 2007). Third, grasshopper densities or species compositions on a local scale are distributed spatially in a way that may reflect spatial heterogeneity in food quality (Heidorn and Joern 1987, White 1993, Haddad et al. 2001, Loaiza et al. 2011). We ask three primary questions: (1) How variable are plant foliar elemental concentrations between grasses and forbs, and between sites? (2) Can variation in foliar element concentrations be linked with the spatial heterogeneity of grasshopper densities at both the taxonomic and feeding guild level, and if so, which elements are most informative? (3) Can variation in plant foliar levels be linked to species composition of grasshopper communities? Our work is comparative without accompanying experimental validation of outcomes, but the scope of comparisons is broad, and highly informative. We also identify a suite of elements whose functional/physiological effects on insect herbivores warrant further investigation.

\section{Methods}

\section{Site descriptions, grasshopper and vegetation sampling}

Grasshopper abundance and community composition, plant vegetative biomass, and elemental composition from 17 well-dispersed sites from three grassland habitats in western Nebraska, USA (Keith and Arthur counties) were sampled over a five-day period in August 2005 (a period which corresponded with peak emergence of adult grasshoppers). The three grassland habitats included: (1) sandhills grassland (nine sites in total; four from Arapaho Prairie in Arthur County (abbreviated as AP), plus five additional sites in Arthur County (abbreviated as Arthur), (2) mixed-grass prairie on 
low-lying sandy soils (five sites; collected in Keith County, at Cedar Point Biological Station and abbreviated as CPBS), and (3) disturbed areas composed of loamy soils with past heavy grazing and vegetation characterized as "weedy" (three sites; collected in Arthur county, near CPBS; these sites are abbreviated as Dist). Each of the four site abbreviations is used in Figs. 1, 2, 4 , and 5. The maximum distance between any two sites was $\sim 50 \mathrm{~km}$ and the closest $\sim 0.6 \mathrm{~km}$. Sites differ in soil composition, landscape position, historical land use, and current grazing levels among the three habitats (sandhills, mixed grassland, and disturbed sites). Soils in this study ranged from sites with moderate to strongly sloping well-drained Valentine fine sand to those dominated by Bayard fine sandy loams or Keith loams on gently to moderate slopes (NRCS soil maps). Grazing intensity also varied and likely influenced grasshopper abundance, leaf area index, and plant-soil interactions (O'Neill et al. 2003).

Grasshopper densities and community species compositions were quantified using the standardized ring count method (Onsager 1977, Joern 2005) and sweep sampling (Evans et al. 1983). These methods accurately assess density and species composition, respectively, in grassland habitats characteristic of the study area. At each site, four $\sim 100 \mathrm{~m}$ long transects spaced at least 10 $\mathrm{m}$ apart were sampled. Twenty $0.1-\mathrm{m}^{2}$ area rings were placed randomly along each transect with a minimum distance of at least $2 \mathrm{~m}$ between each ring. This distance was sufficient to limit interference with the next uncounted ring during the actual sampling process. After several hours to allow natural redistribution of grasshoppers, transects were walked slowly and individuals located in each ring were counted.

Relative abundances of grasshoppers were estimated using sweep sampling. Systematic sweeping using nets (32 cm diameter) was conducted until 200 sweeps were completed. Nets were emptied after every 25 sweeps; the entire sample was bulked to estimate relative abundances of species for each site. This technique provides reliable estimates of relative abundance of grasshoppers in grassland habitats (Evans et al. 1983). Species densities at each site were determined by multiplying relative abundances of individual species by the overall grasshopper density. Relative abundances of grasshopper species for sampled localities are shown in Appendices A and B. Vegetation biomass was estimated by averaging clipped vegetation at $1 \mathrm{~cm}$ above ground level for $100.1-\mathrm{m}^{2}$ plots located randomly along each of the four transects at each site. Vegetation was sorted to grass and forb, dried for $36 \mathrm{~h}$ at $55^{\circ} \mathrm{C}$, and weighed to estimate total biomass $\left(\mathrm{g} / \mathrm{m}^{2}\right)$ at each site. Only grass biomass was included in analyses of grass-feeding grasshopper responses and only forb biomass was included in models for forb-feeding grasshoppers. Total plant biomass was used for analyses including mixedfeeding grasshoppers and all taxa combined. Plant tissue was then prepared for elemental analysis, including $\mathrm{N}$,
$\mathrm{P}, \mathrm{S}, \mathrm{B}, \mathrm{Ca}, \mathrm{Mg}, \mathrm{Na}, \mathrm{K}, \mathrm{Zn}, \mathrm{Fe}, \mathrm{Mn}$, and $\mathrm{Cu}$, as detailed in Appendix C.

\section{Statistical analyses}

First we examined how foliar elemental content varied between plant type (forb and grass) and among 17 unique sites, from three different grassland habitats (sandhills grassland, mixed-grass prairie, and disturbed areas). We evaluated responses using MANOVA techniques (JMP version 7.0.2; SAS Institute, Cary, North Carolina, USA) because elemental levels in plant vegetative tissues are not independent of one another. Where significant differences were observed with respect to site, contrasts were employed to compare elemental profiles across the three sites (sandhills vs. mixed-grass, sandhills vs. disturbed, and mixed-grass vs. disturbed). For each element we also performed univariate analyses at the site level (using Bonferroni adjustments to avoid Type I errors). Finally, we compared the absolute concentration of each element in forbs and grasses by calculating a forb: grass element ratio for each element at each site. This ratio was analyzed using a $t$ test with a hypothesized mean of 1 (a value indicating absolute elemental amounts were equal in paired forb and grass comparisons).

We next employed a model selection approach following Akaike's Information Criterion $\left(\triangle \mathrm{AIC}_{\mathrm{c}}\right)$ corrected for small sample sizes to explore links between foliar concentrations of elements with the spatial heterogeneity of grasshopper density among sites. This approach is particularly well suited for making inferences on observational data collected from complex systems (Burnham and Anderson 2002, Johnson and Omland 2004). In total, 36 candidate models (Appendix D) were generated using combinations of elements for which biological reasons predicted performance effects, and fit to the data using linear regression (PROC GENMOD; SAS version 9.1, SAS Institute, Cary, North Carolina, USA). Calculated $\mathrm{AIC}_{\mathrm{c}}$ weights $\left(w_{i}\right)$ were used to assess the fit of each model (model $w_{i}$ values range between 0 and 1; higher $w_{i}$ values indicate a better fit of data to a given model). Evidence ratio (ER) values, which represent the likelihood that the best model (bm) is true compared to model $i$ were also calculated (ER = $w_{\mathrm{bm}} / w_{i}$ for all $i$ models where the best model is the model with the highest $w_{i}$ ).

Finally, species composition of the grasshopper communities and its relationship to foliar elemental levels and plant biomass was examined using two approaches. First, hierarchical clustering of sites based on grasshopper species composition was performed to determine if sites from the same habitat type and location were most similar. Second, grasshopper communities (relative abundances) were ordinated (32 species at 16 sites) by principal components analysis (PCA) using variance/covariance matrices for grasshopper species among sites. Ordination scores were calculated using distance-based biplot methods, while site- 

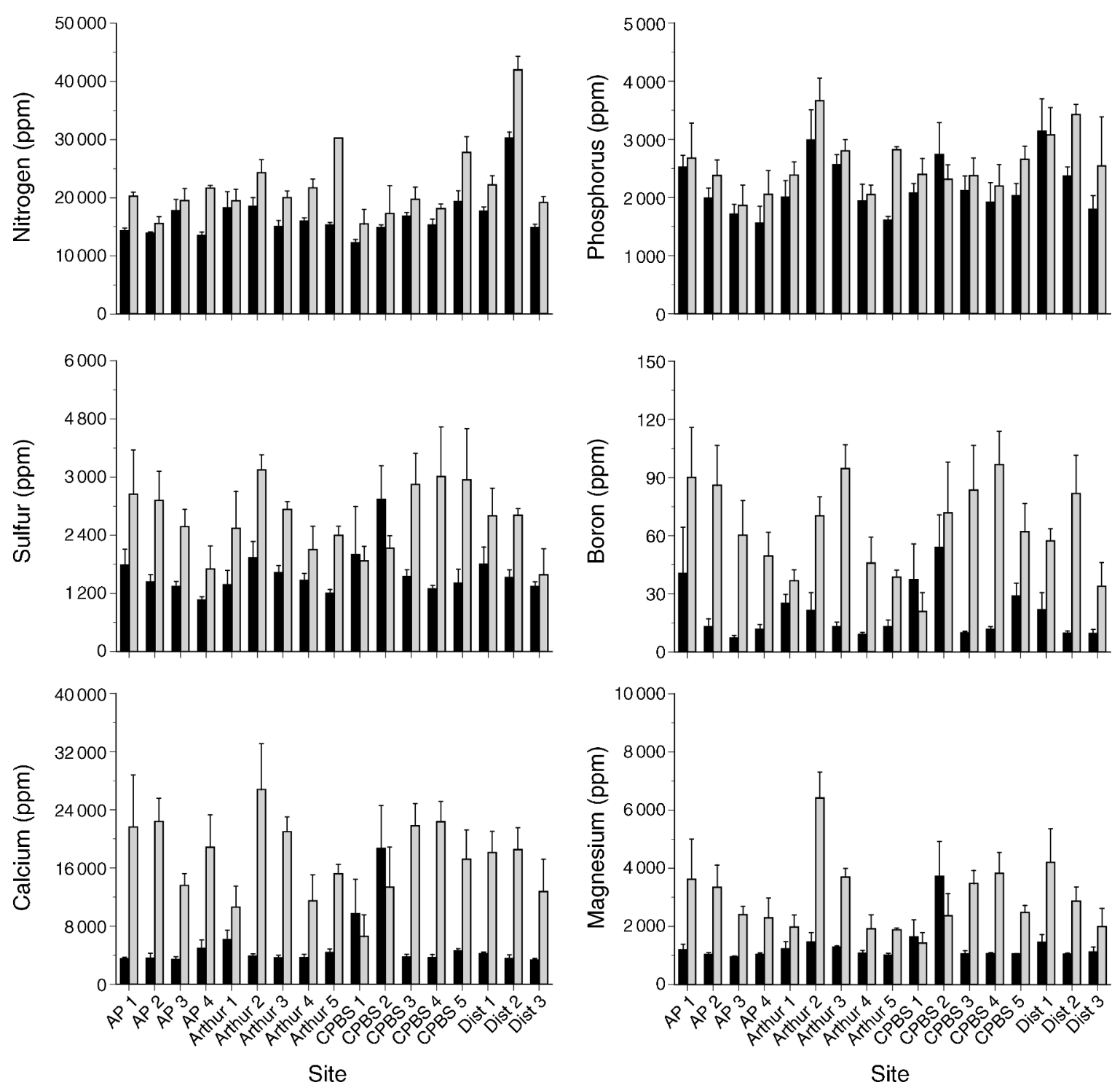

FIG. 1. Concentrations (mean $+\mathrm{SE})$ of nitrogen $(\mathrm{N})$, phosphorus $(\mathrm{P})$, sulfur $(\mathrm{S})$, boron $(\mathrm{B})$, calcium $(\mathrm{Ca})$, and magnesium $(\mathrm{Mg})$ in bulked grass and forb tissue from 17 grassland sites in western Nebraska, USA (for conversion to percentage dry mass: 100 ppm $=0.01 \%, 1000 \mathrm{ppm}=0.1 \%$, and $10000 \mathrm{ppm}=1 \%$ ). The AP (Arapaho Prairie) and Arthur (Arthur County) sites represent sandhills grassland (nine sites); the CPBS (Cedar Point Biological Station) sites represent mixed-grass prairie (five sites); and the Dist (disturbed areas, near CPBS) sites represent areas with past heavy grazing and vegetation characterized as "weedy" (three sites).

based ordinations were plotted with the contribution of environmental variables from plant elemental composition and average plant biomass. Both of the above analyses were performed using PCORD (version 5) (McCune and Mefford 1999, McCune and Grace 2002).

\section{Results}

\section{Foliar concentrations of elements}

Concentrations (mean $+\mathrm{SE}$ ) of 12 foliar elements in grasses and forbs from nine sandhills, five mixedgrassland, and three disturbed sites are shown in Figs. 1 and 2. A MANOVA of elemental composition revealed significant differences in elemental profiles as a result of site $\left(F_{192,1320}=2.03, P<0.001\right)$. Contrasts comparing the three grassland habitats (sandhills, mixed-grass, and disturbed sites) revealed significant differences in plant elemental composition between each habitat (sandhills vs. mixed-grass, $F_{12,99}=2.73, P=$ 0.003; sandhills vs. disturbed, $F_{12,99}=9.48, P<0.001$; disturbed vs. mixed-grass, $\left.F_{12,99}=14.56, P<0.001\right)$. At the univariate level, there were site differences for only six elements (for the following analyses, $\mathrm{df}=16,110$ ): nitrogen $(F=15.23, P<0.001)$, phosphorus $(F=3.58, P$ $<0.001)$, magnesium $(F=2.35, P=0.005)$, sodium $(F=$ 5.06, $P<0.001)$, potassium $(F=3.23, P<0.001)$, and copper $(F=6.92, P<0.001)$. This same MANOVA also 

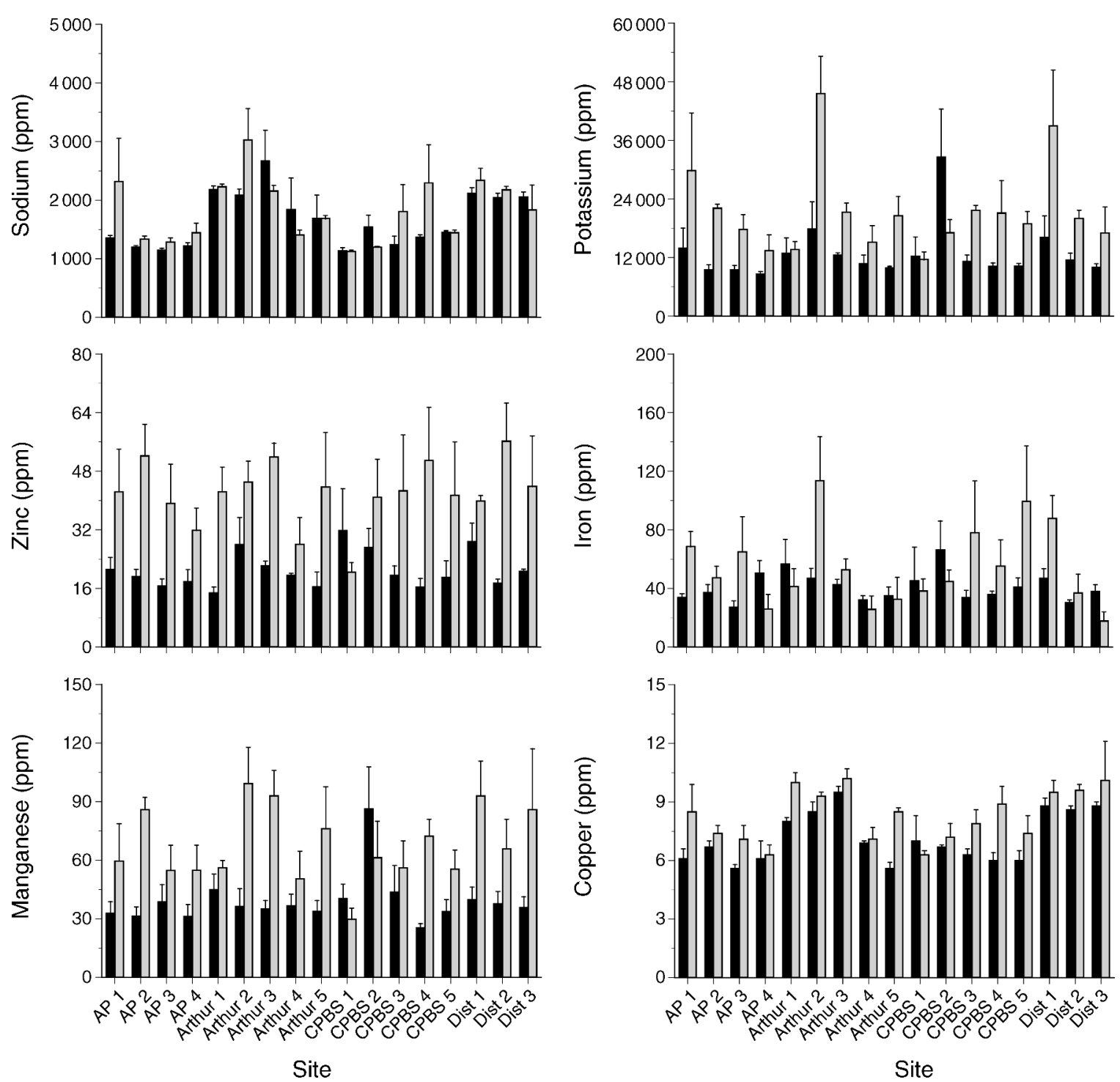

FIG. 2. Concentrations (mean $+\mathrm{SE})$ of sodium $(\mathrm{Na})$, potassium $(\mathrm{K})$, zinc $(\mathrm{Zn})$, iron $(\mathrm{Fe})$, manganese $(\mathrm{Mn})$, and copper $(\mathrm{Cu})$ in bulked grass and forb tissue from 17 continental grassland sites in western Nebraska (for conversion to percentage dry mass: 100 $\mathrm{ppm}=0.01 \%, 1000 \mathrm{ppm}=0.1 \%$, and $10000 \mathrm{ppm}=1 \%$ ). The AP and Arthur sites represent sandhills grassland (nine sites); the CPBS sites represent mixed-grass prairie (five sites); and the Dist sites represent areas with past heavy grazing and vegetation characterized as weedy (three sites).

revealed significant differences in elemental patterns between grasses and forbs $\left(F_{12,99}=13.01, P<0.001\right)$, with forbs having significantly higher elemental concentrations. Univariate tests at the plant level revealed that all elements except for $\mathrm{Na}$ and $\mathrm{Fe}$ were recorded at higher concentrations in forbs compared to grasses (using corrected $P$ values). These results were confirmed by a ratio analysis (Fig. 3).

\section{Overall grasshopper densities}

Overall grasshopper densities (Fig. 4a) varied significantly among all sites (nested within habitat; $F_{14,51}=$ 6.7, $P<0.001)$, an approximately sevenfold difference that ranged from 3 to 21.5 individuals $/ \mathrm{m}^{2}$. Significant variation of grasshopper densities among habitat types was also evident $\left(F_{2,51}=73.3, P<0.001\right)$. The feeding guild composition of each site expressed as a percentage of the total is shown in Fig. 4b.

Using $\mathrm{AIC}_{\mathrm{c}}$ criteria, we next regressed total grasshopper density with elemental composition, and plant biomass, to identify which of our 36 initial models (Appendix D) best fit the data (defined as having $w_{i}$ values $>0.1$ ). As seen in Table $1 \mathrm{a}$, three $\mathrm{AIC}_{\mathrm{c}}$ models met our criteria. Phosphorus was a critical element for the two best-fit models, but total vegetative biomass plus $\mathrm{S}$ and $\mathrm{Mn}$ also emerged as potentially important factors associated with grasshopper densities. Interestingly, N did not emerge as an important element explaining 


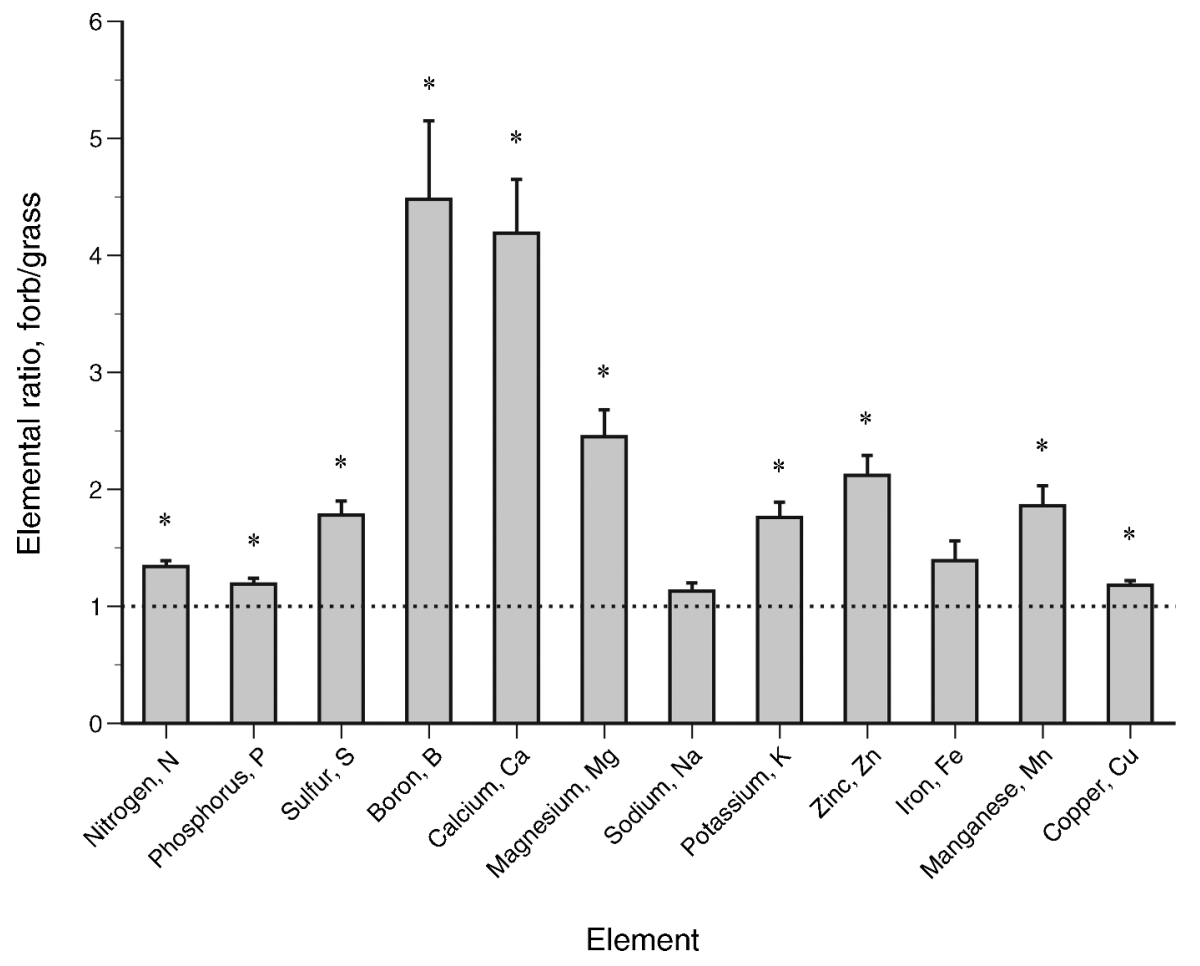

FIG. 3. Ratio of elemental concentrations (mean $+\mathrm{SE}$ ) in forbs vs. bulked grasses, averaged over all sites. Statistically significant differences were determined based on $t$ test comparisons, using a null model of 1 (equal ratios, as shown by the dashed line). An asterisk above a bar indicates that for that element the forb/grass ratio was statistically significant $(>1)$.

$* P<0.05$.

variation of total densities of all grasshopper species among sites. This result is reinforced by importance values (Table 2), which indicates that $\mathrm{P}$ is the best explanatory variable followed by plant biomass, S, B, and $\mathrm{Mn}$.

\section{Density responses of feeding guilds}

An $\mathrm{AIC}_{\mathrm{c}}$ approach was next applied to grasshoppers based on their feeding guild. Densities of grass-feeders responded consistently to $\mathrm{N}$ and $\mathrm{P}$ concentrations, with $\mathrm{N}$ occurring in the top three models $\left(w_{i}>0.1\right)$, and $\mathrm{P}$ occurring in second and third ranked models (Table 1b). The second ranked model suggested $\mathrm{Ca}, \mathrm{Na}$, and $\mathrm{Mg}$, as well as grass biomass, were also potentially important variables for grass-feeders. Inspection of importance values of elements for the entire range of models (Table 2) suggests that $N$ and $P$ are the variables that best explain spatial heterogeneity in grass-feeding grasshopper densities.

For forb-feeders, a range of elements was associated with densities, but $\mathrm{N}$ and $\mathrm{P}$ appeared to be the most important foliar elements based on the frequency at which they occurred in models with $w_{i}>0.1$ (Table 1c). Interestingly, forb biomass alone generated the best-fit model, and in the fourth- and fifth-ranked models B, Ca, $\mathrm{Na}, \mathrm{K}$, and $\mathrm{Zn}$ were identified as important. Inspection of importance values (Table 2) suggested that $\mathrm{N}$ and $\mathrm{P}$ had the largest effect on densities of forb-feeding grasshoppers, followed by forb biomass, and S.

The third feeding guild, the mixed-feeders, showed positive associations of density with plant biomass and seven elements. Based on frequency of occurrence in models with $w_{i}>0.1$, vegetation biomass followed by $\mathrm{P}$ are most important variables (Table 1d). However, the best-fit model (the one with the highest $w_{i}$ value) suggests that $\mathrm{S}, \mathrm{B}, \mathrm{Mg}, \mathrm{Na}, \mathrm{K}$, and $\mathrm{Cu}$ are all potentially important elements for mixed-feeding grasshoppers. Overall importance values revealed that plant biomass is the dominant factor associated with the density of mixed-feeding grasshoppers, but also suggest a role for $\mathrm{P}, \mathrm{S}, \mathrm{B}, \mathrm{Mg}, \mathrm{Na}$, and $\mathrm{Cu}$ (Table 2).

\section{Grasshopper community species composition}

Grasshopper species composition varied among sites in two important ways. First, as shown by the dendrogram of species similarity among communities (Fig. 5a), similarity of species composition among sites was not a result of spatial proximity or grassland habitat types. Second, PCA ordination of species assemblies among sites from our three grassland habitats (Fig. 5b) indicated that shifts in species composition were associated with changes in foliar nutrient content and total plant biomass. Overall, our ordination of species composition among sites explained $85 \%$ of the variation, 

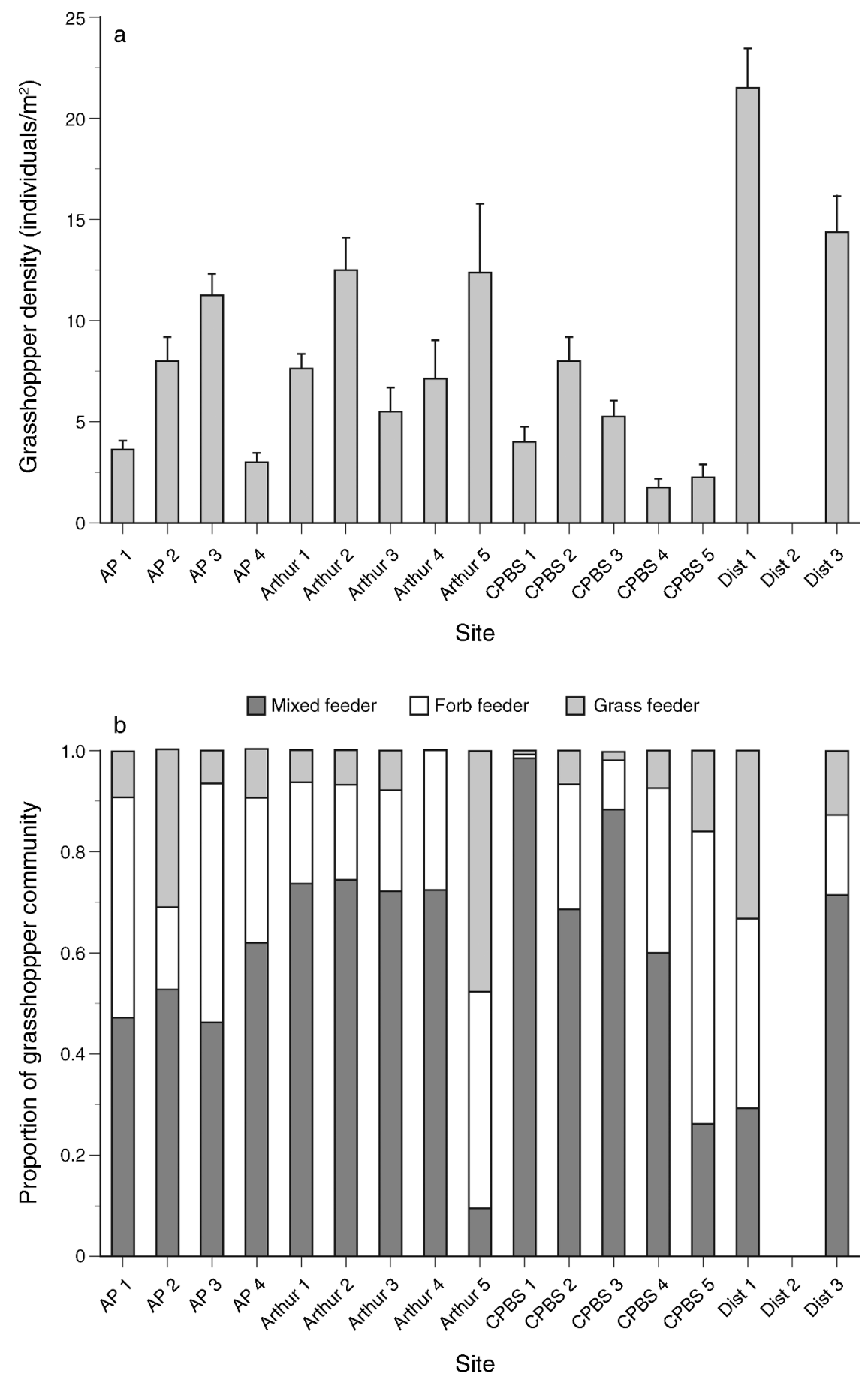

FIG. 4. Grasshopper densities and relative proportions at each site. (a) Overall grasshopper densities (mean + SE) for each site, all species combined. (b) Proportion of the grasshopper community in each feeding guild for each site. The AP and Arthur sites represent sandhills grassland (nine sites); the CPBS sites represent mixed-grass prairie (five sites); and the Dist sites represent areas with past heavy grazing and vegetation characterized as weedy (three sites). Grasshopper data for Dist 2 site were missing.

with the first three axes (dominant eigenvalues) explaining $53.9 \%, 20.0 \%$, and $11.3 \%$ of the total variation in species composition among sites, respectively. Although none of our environmental correlates (foliar element concentrations or biomass) corresponded strongly to axis 1, plant biomass, $\mathrm{Cu}$, and $\mathrm{Zn}$ were correlated significantly with axis 2 (Fig. 5b). On axis 3, foliar variation in $\mathrm{Ca}$ and $\mathrm{B}$ levels were identified as important correlates explaining grasshopper community species composition (Fig. 5b). 
TABLE 1. Summary of results identifying the best sets of models to predict grasshopper density, for all species and by guild, using Akaike information theory criteria over 16 grassland sites in western Nebraska, USA.

\begin{tabular}{llllll}
\hline \hline Model number & $\mathrm{AIC}_{\mathrm{c}}$ & $\Delta w$ & $w_{i}$ & $\mathrm{ER}$ & \multicolumn{1}{c}{$\begin{array}{c}\text { Important variables } \\
\text { in model }\end{array}$} \\
\hline a) All species & & & & & \\
$\quad$ Model 6 & 97.70 & & 0.37 & 1 & $\mathrm{P}$ \\
$\quad$ Model 5 & 99.56 & 1.85 & 0.15 & 2.52 & biomass, P \\
$\quad$ Model 33 & 99.6 & 1.89 & 0.14 & 2.58 & $\mathrm{~S}, \mathrm{Mn}$ \\
b) Grass-feeding species & & & & & \\
Model 4 & 74.12 & & 0.39 & 1 & $\mathrm{~N}$ \\
Model 18 & 75.23 & 1.11 & 0.23 & 1.74 & $\mathrm{~N}, \mathrm{P}, \mathrm{Ca}, \mathrm{Mg}, \mathrm{Na}$ \\
$\quad$ Model 8 & 75.90 & 1.78 & 0.16 & 2.44 & $\mathrm{~N}, \mathrm{P}$ \\
c) Forb-feeding species & & & & & \\
$\quad$ Model 1 & 72.89 & & 0.13 & 1 & biomass \\
Model 6 & 72.90 & 0.02 & 0.13 & 1.01 & $\mathrm{P}$ \\
$\quad$ Model 4 & 73.16 & 0.27 & 0.12 & 1.15 & $\mathrm{~N}$ \\
Model 22 & 73.25 & 0.35 & 0.11 & 1.19 & $\mathrm{~N}, \mathrm{P}, \mathrm{Ca}, \mathrm{Na}, \mathrm{K}, \mathrm{Zn}$ \\
Model 36 & 73.27 & 0.38 & 0.11 & 1.21 & $\mathrm{~B}$ \\
d) Mixed-feeding species & & & & & \\
$\quad$ Model 26 & 68.35 & & 0.36 & 1 & biomass, K, Na, Mg, Cu, S, B \\
$\quad$ Model 5 & 69.62 & 1.26 & 0.19 & 1.88 & biomass, P \\
Model 1 & 69.89 & 1.53 & 0.17 & 2.15 & biomass \\
Model 6 & 70.68 & 2.33 & 0.11 & 3.20 & $\mathrm{P}$ \\
\hline
\end{tabular}

Notes: Highest ranked models assessing the importance of total biomass and mineral nutrients on variation among sites are shown for grasshopper density of all species combined and by feeding guild. $\mathrm{AIC}_{\mathrm{c}}$ is the information theoretic criterion corrected for small sample size, $\Delta w$ indicates the plausibility that the fitted model matches the best possible model (calculated as the difference between a model's $\mathrm{AIC}_{\mathrm{c}}$ score and the best $\mathrm{AIC}_{\mathrm{c}}$ score), $w_{\mathrm{i}}$ is a normalized Akaike weight, which represents the relative likelihood of the model given the data, and ER (evidence ratio, calculated as the best Akaike weight divided by a given model's Akaike weight) is the relative likelihood of model $i$ vs. another model $j$ in rightly predicting the correct model for the sampling scheme (Burnham and Anderson 2002). The list of models included in this analysis is shown in Appendix D, but only models that generated $w_{i}$ values of $>0.1$ are shown here (see the Methods section for more details). The relative importance of elements for the range of models examined in this study is shown in Table 2.

Table 2. Relative importance of elements for the range of models examined in this study, calculated as the sum of $w_{i}$ from all models in which a given variable occurs (see Appendix D for all models tested).

\begin{tabular}{lcccc}
\hline \hline \multicolumn{1}{c}{ Variable } & All species & Grass-feeders & Forb-feeders & Mixed-feeders \\
\hline Vegetative biomass & $\mathbf{0 . 2 4 2}^{(\mathbf{2})}$ & 0.129 & $\mathbf{0 . 2 8 5}^{(2)}$ & $\mathbf{0 . 7 4 7}^{(1)}$ \\
Nitrogen (N) & 0.118 & $\mathbf{0 . 9 1 8}^{(1)}$ & $\mathbf{0 . 3 7 2}^{(1)}$ & 0.062 \\
Phosphorus (P) & $\mathbf{0 . 5 9 9}^{(1)}$ & $\mathbf{0 . 4 8 9}^{(2)}$ & $\mathbf{0 . 3 9 1}^{(1)}$ & $\mathbf{0 . 3 2 4}^{(3)}$ \\
Sulfur (S) & $\mathbf{0 . 2 3 8}^{(2)}$ & 0.021 & $\mathbf{0 . 1 9 5}^{(3)}$ & $\mathbf{0 . 4 3 7}^{(2)}$ \\
Boron (B) & $\mathbf{0 . 2 0 5}^{(2)}$ & 0.013 & 0.125 & $\mathbf{0 . 4 1 2}^{(2)}$ \\
Calcium (Ca) & 0.041 & $\mathbf{0 . 2 5 1}^{(3)}$ & 0.158 & 0.002 \\
Magnesium (Mg) & 0.040 & $\mathbf{0 . 2 3 3}^{(3)}$ & 0.007 & $\mathbf{0 . 3 6 1}^{(3)}$ \\
Sodium (Na) & 0.031 & $\mathbf{0 . 2 4 8}^{(3)}$ & 0.155 & $\mathbf{0 . 3 6 0}^{(3)}$ \\
Potassium (K) & 0.002 & 0.018 & 0.152 & $\mathbf{0 . 3 5 9}^{(3)}$ \\
Zinc (Zn) & 0.002 & 0.00 & 0.144 & 0.002 \\
Iron (Fe) & 0.017 & 0.00 & 0.013 & 0.006 \\
Manganese (Mn) & $\mathbf{0 . 1 6 3}$ & 0.082 & 0.043 \\
Copper (Cu) & 0.003 & 0.001 & 0.002 & $\mathbf{0 . 3 6 1}$ \\
\hline
\end{tabular}

Notes: Comparing the relative importance helps one to recognize relative strengths of the variables (Burnham and Anderson 2002). All independent variables shown here were included in the same number of models $(n=15)$. Variables from models that had $w_{i}$ values $>0.1$ (our cutoff value for inclusion) are shown in bold. Superscripted numbers in parentheses indicate, within each column, the rank of a variable's relative importance when all 15 models containing that variable are considered. The top three groups of variables are shown, and where relative importance values are similar, they are assigned the same relative rank. For example, for the mixed-feeder guild, five variables are assigned 3's because they fall within a similar range $(0.324-0.361)$. 


\section{DiscusSION}

The dynamics of insect herbivore populations and their community structure result from the combined effects of multiple bottom-up and top-down processes, but the success of insect herbivores at the individual level remains fundamentally tied to plant nutritional quality (Denno and McClure 1983, Rosenthal and Berenbaum 1992, White 1993). Laboratory studies provide detailed mechanistic and functional insights into how food quality affects insect herbivores because they allow precise manipulation and control of key dietary nutrients and allelochemicals (Raubenheimer and Simpson 1993, Trumper and Simpson 1993, Behmer and Elias 2000, Simpson and Raubenheimer 2001, Behmer et al. 2002). But because ecologists are ultimately interested in natural responses by insect herbivores, it is critical to investigate how insect herbivores respond to natural variation in host plant nutritional quality (defined beyond one or two variables). We readily acknowledge the considerable contributions of laboratory feeding studies to nutritional ecology, but our approach in this current study is to let natural variation point to key relationships between plant quality and grasshopper responses. In doing so, we have uncovered interesting correlations between grasshopper abundances/species compositions and foliar elements, some which have been rarely examined. Our results also suggest that certain understudied nutrients warrant further investigation at a functional/mechanistic level.

Before discussing our results, we make three important caveats. First, although our efforts focus on describing grasshopper abundance and species community composition with respect to plant nutritional (measured in terms of elements) and biomass traits, we realize that insect herbivore distributions and abundances can also interact and covary with a range of nonnutritional factors, including: vegetation structure and plant species composition (Haddad et al. 2001, Joern 2004), resource complementation (Beckerman 2002), behavioral limits affecting local dispersal (With and Crist 1995, Haynes and Cronin 2006), predation risk (Schmitz et al. 1997, Cronin et al. 2004, Danner and Joern 2004, Schmitz 2009, Hawlena and Schmitz 2010), and larger-scale landscape features than that studied here (Haynes et al. 2007). Second, we acknowledge that what is measured in plants, and what is available to insect herbivores, are not necessarily equal. For example, cell wall morphology $\left(\mathrm{C}_{3}\right.$ vs. $\left.\mathrm{C}_{4}\right)$ and leaf age (new vs. old) can affect nutrient extraction efficiency (Clissold et al. 2006, 2009). By bulking plant samples (grass samples represent multiple species as do forb samples), and only sampling green plant tissue, we hope that such plant-specific effects will have been subsumed. Third, we did not assess carbon (C) in our analyses. Although $\mathrm{C}$ is the most abundant element in plants, and is often used as a proxy for available energy, plant total-C is not particularly informative. Carbon is contained in all major biomolecules, but its content in these biomole- cules is highly variable; the average $\mathrm{C}$ content of carbohydrates, proteins, and lipids is $\sim 37 \%, \sim 53 \%$, and $\sim 70 \%$, respectively (Sterner and Elser 2002). This means that identifying the plant source of $\mathrm{C}$ and its functional role (e.g., energy vs. structural) is crucial. It is also the case that a large fraction of plant carbohydrate$\mathrm{C}$ is contained within cellulose and lignin (Marschner 1995), which is not digestible by most insect herbivores (Chapman 1998). Thus, attempts to treat C as a nutrient for insect herbivores and/or to use it as a surrogate for available energy are highly problematic, and should be avoided (Anderson et al. 2004, Raubenheimer et al. 2009).

It is now well established that foliar elemental composition of plants can be highly variable in response to local environmental conditions (Clarkson 1985, Chapin et al. 1987, Chapin 1991, Aerts and Chapin 2000). We also found significant variation in patterns of foliar elements among habitats and individual sites, but our univariate analysis of individual elements showed that significant variation across sites occurred for only six of our 12 foliar elements: $\mathrm{N}, \mathrm{P}, \mathrm{Mg}, \mathrm{Na}, \mathrm{K}$, and $\mathrm{Cu}$. Of these, $\mathrm{N}, \mathrm{P}, \mathrm{Mg}$, and $\mathrm{K}$ are categorized as plant macronutrients, while $\mathrm{Na}$ and $\mathrm{Cu}$ are considered micronutrients (Mills and Jones 1996). On average, forbs contained higher concentrations of mineral elements (except $\mathrm{Na}$ and $\mathrm{Fe}$ ) compared to grasses, and these differences were sometimes large (B, Ca, $\mathrm{Mg}$, and $\mathrm{Zn}$ ). Such differences in foliar elemental concentrations between dicots and monocots have been long known (Marschner 1995), and this suggests that forbs relative to grasses have greater absolute nutritional value.

Having documented the extent of natural variation in foliar elements, our next goal was to evaluate how this variation might inform spatial variability in grasshopper abundances, both at the broad family taxonomic level (Acrididae), and the feeding-guild level (grass-, forb-, and mixed-feeder). The two foliar elements consistently viewed as being important for insect herbivores are $\mathrm{N}$ (Heidorn and Joern 1987, Haddad et al. 2000, Apple et al. 2009, Bishop et al. 2010, Loaiza et al. 2011) and P (Schade et al. 2003, Kay et al. 2004, Apple et al. 2009, Bishop et al. 2010), but only $\mathrm{P}$ was significantly correlated with total grasshopper abundance across the four grouping levels. Apple et al. (2009) found that naturally occurring foliar $\mathrm{P}$ levels were positively correlated with caterpillar survival and growth rate at an early primary succession terrestrial habitat. At this same site, Bishop et al. (2010) also documented that P addition promoted orthopteran abundance (primarily Melanoplus spp. [Acrididae] and mormon crickets [Tettigoniidae]). Our results are consistent with the notion that $\mathrm{P}$ might constrain insect herbivore populations in terrestrial ecosystems. An alternative possibility is that plants with higher $\mathrm{P}$ levels may have higher photosynthetic rates, and thus provide greater energetic value. However, $\mathrm{P}$ in and of itself can limit insect herbivore growth (Perkins et al. 2004), and grasshop- 
a

Distance (objective function)

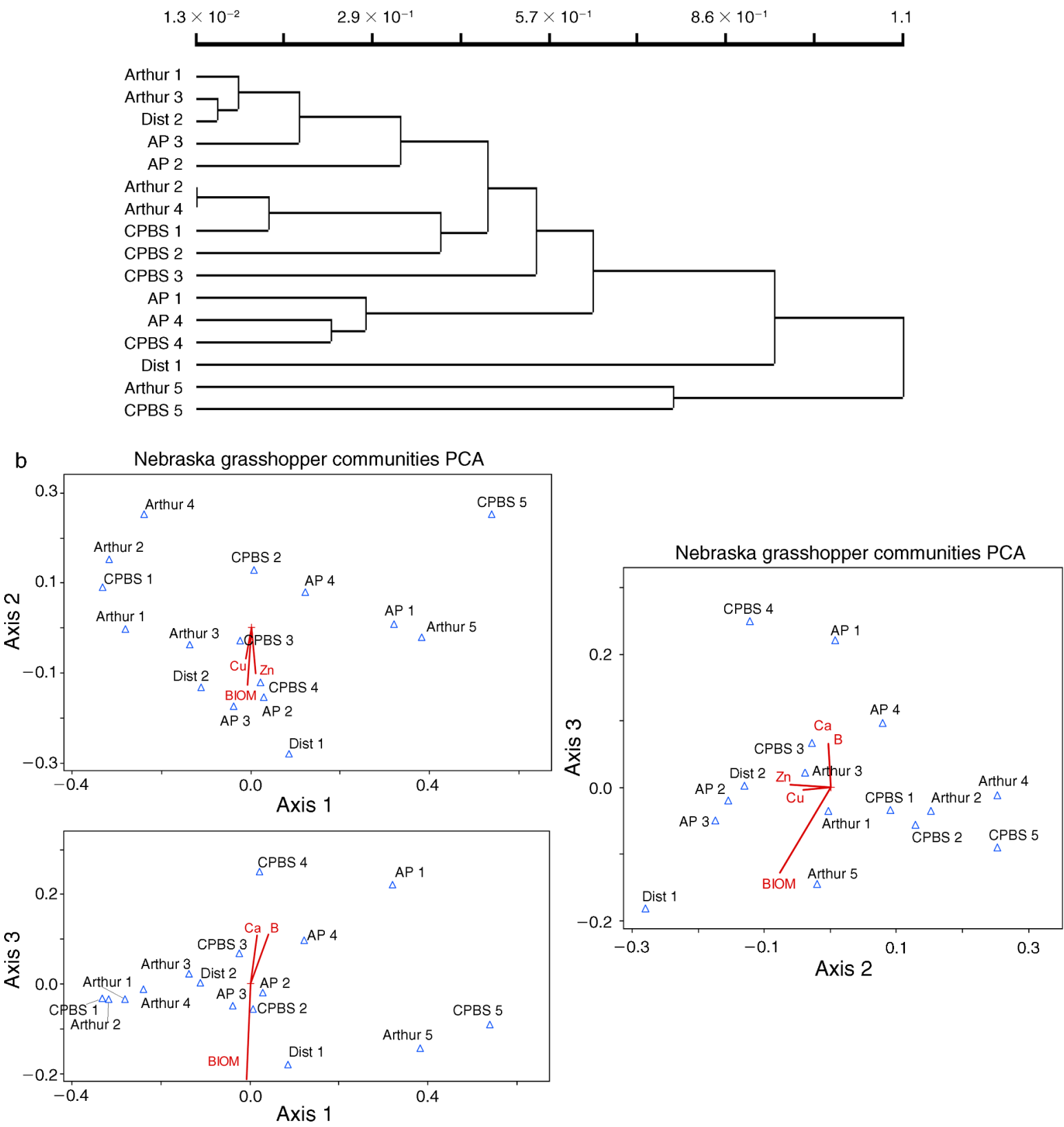

FIG. 5. Hierarchical clustering of grasshopper sites and ordination of grasshopper communities using PCA. (a) Similarity of species composition among sites was not a result of spatial proximity or grassland habitat types (AP 1-4 and Arthur 1-5, sandhills grassland; CPBS 1-5, mixed-grass prairie; and Dist 1-2, habitats with loamy soils and vegetation characterized as weedy; here Dist 2 equals Dist 3 in Figs. 1, 2, and 4, and grasshopper data for our third disturbed site were missing). (b) Grasshopper communities (relative abundances) ordinated (32 species at 16 sites) by principal components analysis (PCA) using variance/covariance matrices for grasshopper species among sites. The first three dominant axes explained $85 \%$ of the variation $(53.9 \%$ for axis $1,20.0 \%$ for axis 2 , and $11.3 \%$ for axis 3 ). None of our measurements correlated significantly with axis 1 . Plant biomass, $\mathrm{Cu}$, and $\mathrm{Zn}$ were important correlates on axis 2 , while $\mathrm{Ca}$ and $\mathrm{B}$ levels were important correlates on axis 3 .

pers/orthopterans certainly are good candidates to be $\mathrm{P}$ limited. A recent detailed laboratory study using a generalist grasshopper revealed $\mathrm{P}$ tissue levels at $\sim 10000$ ppm (1\% dry mass) (Boswell et al. 2008), which is three to four times higher than the $\mathrm{P}$ concentrations recorded in our plants (see Fig. 1).
That $\mathrm{N}$ was not significant in our models across the board (as with $\mathrm{P}$ ) was unexpected considering that for the last three decades $\mathrm{N}$ generally has been considered the most important nutrient for insect herbivores (Mattson and Haack 1987, White 1993, 2008). It is now recognized that protein to carbohydrate ratios are 
more important than protein alone (Raubenheimer and Simpson 1993, Raubenheimer et al. 2009), and that insect herbivores can balance diets to meet multidimensional nutritional demands. Moreover, this makes it difficult to generalize results from elemental concentrations without additional experimental tests because of problems in inferring carbohydrate concentrations from $\mathrm{C}$ alone as discussed previously. Interestingly, $\mathrm{N}$ was strongly associated with the abundance of both grass-feeding grasshoppers, which were the dominant feeding guild at most of our sites (often comprising 50$70 \%$ of the total), and forb-feeding grasshoppers (occurring in two out of five significant models, and having a high relative evidence ratio [ER] score). In contrast, $\mathrm{N}$ was not correlated with abundance of mixed-feeders, which regularly consume significant quantities of both grasses and forbs (Joern 1985). Perhaps this suggests that plant $\mathrm{N}$ levels are most informative with respect to population abundance of specialist insect herbivores on only grasses or forbs. For generalist insect herbivores, foliar- $\mathrm{N}$ levels may be less useful because eating a broad diet may allow them to reach their preferred $\mathrm{N}$ (protein) intake by switching back and forth between high-N (forbs) and low-N (grasses) plants (Jonas and Joern 2008).

We also documented variability in grasshopper abundances to variable foliar concentrations of $\mathrm{Mg}$, $\mathrm{Na}, \mathrm{K}$, and $\mathrm{Cu}$ levels. How might these additional elements affect insect herbivores? Like $\mathrm{N}, \mathrm{Mg}$ is used for structural purposes, $\mathrm{Na}$ and $\mathrm{K}$ are involved in electrochemical function, including message transmission in nerves, cellular signaling, and energy metabolism, and $\mathrm{Cu}$ is used in catalytic roles (Fraústo da Silva and Williams 1991). With the exception of $K$, these elements are found at low concentrations in plants and insect herbivores (Boswell et al. 2008). However, low concentration does not mean these nutrients cannot influence ecological processes. For example, the nutritional value of $\mathrm{Na}$ is well illustrated by puddling behavior in insects (Smedley and Eisner 1995, Molleman 2010), its influence on host plant selection in moose (Belovsky and Jordan 1981), its effect on marching in Mormon crickets (Simpson et al. 2006), ant recruitment to baits (Kaspari and Yanoviak 2009, Kaspari et al. 2009), and other invertebrate responses in tropical brown food webs (Kaspari and Yanoviak 2009). In our study, $\mathrm{Na}$ was the only element (other than P) identified in at least one model for each of our three feeding guilds. Very little is known about how variation in foliar $\mathrm{Mg}$ and $\mathrm{K}$ might affect insect herbivores, but these two elements were each included twice in significant models (see Table 1). Interestingly, some elements that did not show great variation in plants were nonetheless included as significant elements in models. These included S, Ca, and B (each found in two significant models), plus $\mathrm{Mn}$ and $\mathrm{Zn}$ (each in one significant model). Each of these elements is found at significantly higher concentrations in forbs relative to grasses, especially Ca and B (Fig. 3), so perhaps they are important nutrients for insect herbivores that include forbs in their diet breadth.

Vegetative biomass varied positively with grasshopper abundance with the single exception of grass-feeders. It was also a particularly important variable explaining spatial variation for mixed-feeding grasshoppers, appearing as an important variable in the top three models and exhibiting a high relative importance value $(0.75)$. Although more biomass may indicate more food, an alternative or complementary explanation is that increased biomass leads to increased structure in the habitat, which affects the ability to hide from predators and increase the range of thermal conditions available to insect herbivores within vegetation (Pitt 1999).

As revealed by two separate analyses, spatial variation in foliar elements might also be correlated with variation in taxonomic composition of grasshopper assemblages among sites. First, our hierarchical analysis suggests that community structure is not readily explained by habitat type, or the proximity of sites to one another. Second, our ordination of species abundances explained a large proportion of the variation (85\%) in grasshopper assemblages, and $37 \%$ of this variation was explained by five of our measured variables (biomass, B, Ca, $\mathrm{Zn}$, and $\mathrm{Cu}$ ). We were surprised that $\mathrm{N}$ and $\mathrm{P}$ were not identified as important factors with respect to community structure given their notoriety in the nutritional ecology of insect herbivores, and their frequent occurrence as significant factors explaining grasshopper abundance in our model selection analyses. That $\mathrm{N}$ in particular was not significant is interesting given its link (via protein) to niche differentiation in protein: carbohydrate nutrient space that has been documented for forb and mixed feeding grasshoppers from this same grassland area (Behmer and Joern 2008). Interpreting the biological significance of these explanatory factors at the community level can be challenging, but an inspection of our earlier analyses suggests that much of the explanatory power is linked to grasshoppers that include forbs in their diets. For instance, each of the elements identified as significant in our ordination analysis are significantly higher (absolute levels) in forbs compared to grasses (especially B and $\mathrm{Ca}$ ). Additionally, the elements identified as being important at the community level are identified as important variables in models associated with either forb-feeding or mixed-feeding grasshopper abundance.

Where do we go from here? Moe et al. (2005) argued for the explicit inclusion of elemental constraints in models and empirical studies in order to enhance our ability to explain how populations and communities operate, especially for terrestrial insects. We concur, but with a slight modification-models and empirical studies should focus on nutritional, rather than elemental constraints. Our study demonstrates the utility of this approach, although it seems better suited for questions concerning abundance, rather than 
community structure. Moe et al. (2005) also cautioned against painting with too broad a brush at the taxonomic level. In our case unique insights were obtained by paying attention to important biological criteria, namely host plant type (grasses vs. forbs) and diet breadth (grass specialists, forb specialists, mixedfeeders); we particularly urge nutritional ecologists to be mindful of feeding guild differences when exploring their data. Finally, while our results confirm the general strong correlation effects of $\mathrm{N}$ and $\mathrm{P}$ with insect herbivores, they also highlight the need to think beyond $\mathrm{N}$ and $\mathrm{P}$. In particular, we encourage nutritional ecologists and research broadly interested in insectplant interactions to investigate the nutritional roles of $\mathrm{Na}, \mathrm{Mg}$, and $\mathrm{K}$ for insect herbivores, given that these nutrients vary in plants, and are correlated with grasshopper population abundance.

\section{ACKNOWLEDGMENTS}

We thank members of the Joern Lab (A. Kula, J. Hill, A. Laws, and S. Parsons), the Provin Lab (J. Waskom), and the Behmer Lab (S. C. Cook, M. Le Gall, T. Gates, P. Lenhart, K. Roeder, and X. Jing) for help in processing samples, and for feedback on earlier versions of the manuscript. We also thank David Raubenheimer and one anonymous reviewer for specific suggestions that greatly improved the manuscript. Cedar Point Biological Station (University of Nebraska-Lincoln) provided logistical support of fieldwork. We especially thank J. Jonas for assistance and advice on statistics. This research was supported by an NSF grant (DEB-0456522) awarded to A. Joern and S. T. Behmer and is a contribution of the Kansas Agricultural Experiment Station.

\section{Literature Cited}

Aerts, R., and F. S. Chapin. 2000. The mineral nutrition of wild plants revisited: a re-evaluation of processes and patterns. Advances in Ecological Research 30:1-67.

Anderson, T. R., M. Boersma, and D. Raubenheimer. 2004. Stoichiometry: linking elements to biochemicals. Ecology 85:1193-1202.

Apple, J. L., M. Wink, S. E. Wills, and J. G. Bishop. 2009. Successional change in phosphorus stoichiometry explains the inverse relationship between herbivory and lupin density on Mount St. Helens. PLoS ONE 4:e7807.

Barbosa, P., and J. C. Schultz, editors. 1987. Insect outbreaks. Academic Press, New York, New York, USA.

Beckerman, A. P. 2002. The distribution of Melanoplus femurrubrum: fear and freezing in Connecticut. Oikos 99:131-140.

Behmer, S. T. 2009. Insect herbivore nutrient regulation. Annual Review of Entomology 54:165-187.

Behmer, S. T., and D. O. Elias. 2000. Sterol metabolic constraints as a factor contributing to the maintenance of diet mixing in grasshoppers (Orthoptera: Acrididae). Physiological and Biochemical Zoology 73:219-230.

Behmer, S. T., and A. Joern. 2008. Coexisting generalist herbivores occupy unique nutritional feeding niches. Proceedings of the National Academy of Sciences USA 105:1977-1982.

Behmer, S. T., S. J. Simpson, and D. Raubenheimer. 2002. Herbivore foraging in chemically heterogeneous environments: nutrients and secondary metabolites. Ecology 83:2489-2501.

Belovsky, G. E., and P. A. Jordan. 1981. Sodium dynamics and adaptations of a moose population. Journal of Mammalogy 62:613-621.
Bishop, J. G., N. B. O’Hara, J. H. Titus, J. L. Apple, R. A. Gill, and L. Wynn. 2010. N-P co-limitation of primary production and response of arthropods to $\mathrm{N}$ and $\mathrm{P}$ in early primary succession on Mount St. Helens volcano. PLoS ONE 5:e13598.

Boswell, A. W., T. Provin, and S. T. Behmer. 2008. The relationship between body mass and elemental composition in nymphs of the grasshopper Schistocerca americana. Journal of Orthoptera Research 17:307-313.

Burnham, K. P., and D. R. Anderson. 2002. Model selection and multimodel inference: a practical information-theoretical approach. Springer-Verlag, New York, New York, USA.

Cappuccino, N., and P. W. Price, editors. 1995. Population dynamics: new approaches and syntheses. Academic Press, San Diego, California, USA.

Chapin, F. S. 1991. Integrated responses of plants to stress. BioScience 41:29-36.

Chapin, F. S., A. J. Bloom, C. B. Field, and R. H. Waring. 1987. Plant responses to multiple environmental factors. BioScience 37:49-57.

Chapman, R. F. 1998. The insects: structure and function. Cambridge University Press, Cambridge, UK.

Chapman, R. F., and G. A. Sword. 1997. Polyphagy in the Acridomorpha. Pages 183-195 in S. K. Gangwere, M. C. Muralirangan, and M. Muralirangan, editors. Bionomics of grasshoppers, katydids and their kin. CABI, Wallingford, UK.

Clarkson, D. T. 1985. Factors affecting mineral nutrient acquisition by plants. Annual Review of Plant Physiology and Plant Molecular Biology 36:77-115.

Clissold, F. J., G. D. Sanson, and J. Read. 2006. The paradoxical effects of nutrient ratios and supply rates on an outbreaking insect herbivore, the Australian plague locust. Journal of Animal Ecology 75:1000-1013.

Clissold, F. J., G. D. Sanson, J. Read, and S. J. Simpson. 2009. Gross vs. net income: How plant toughness affects performance of an insect herbivore. Ecology 90:3393-3405.

Cribb, B. W., A. J. A. Stewart, H. Huang, R. Truss, B. Noller, R. Rasch, and M. P. Zalucki. 2008. Insect mandiblescomparative mechanical properties and links with metal incorporation. Naturwissenschaften 95:17-23.

Cronin, J. T., K. J. Haynes, and F. P. Dillemuth. 2004. Spider effects on planthopper mortality, dispersal, and spatial population dynamics. Ecology 85:2134-2143.

Danner, B. J., and A. Joern. 2004. Development, growth and egg production of the common grasshopper, Ageneotettix deorum (Orthoptera: Acrididae) in response to indirect risk of spider predation. Ecological Entomology 29:1-11.

Denno, R. F., and M. S. McClure, editors. 1983. Variable plants and herbivores in natural and managed systems. Academic Press, New York, New York, USA.

Evans, E. W., R. A. Rogers, and D. J. Opfermann. 1983. Sampling grasshoppers (Orthoptera: Acridide) on burned and unburned tallgrass prairie: night trapping vs. sweeping. Environmental Entomology 12:1449-1454.

Feller, U., I. Anders, and T. Mae. 2008. Rubiscolytics: fate of Rubisco after its enzymatic function in a cell is terminated. Journal of Experimental Botany 59:1615-1624.

Fraústo da Silva, J. J. R. and R. J. P. Williams. 1991. The biological chemistry of the elements: the inorganic chemistry of life. Clarendon, Oxford, UK.

Haddad, N., J. Haarstad, and D. Tilman. 2000. The effects of long-term nitrogen loading on grassland insect communities. Oecologia 124:73-84.

Haddad, N. M., D. Tilman, J. Haarstad, M. E. Ritchie, and J. M. H. Knops. 2001. Contrasting effects of plant richness and composition on insect communities: a field experiment. American Naturalist 158:17-35.

Hawlena, D., and O. J. Schmitz. 2010. Herbivore physiological response to predation risk and implications for ecosystem 
nutrient dynamics. Proceedings of the National Academy of Sciences USA 107:15503-15507.

Haynes, K. J., and J. T. Cronin. 2006. Interpatch movement and edge effects: the role of behavioral responses to the landscape matrix. Oikos 113:43-54.

Haynes, K. J., F. P. Dillemuth, B. J. Anderson, A. S. Hakes, H. B. Jackson, S. E. Jackson, and J. T. Cronin. 2007. Landscape context outweighs local habitat quality in its effects on herbivore dispersal and distribution. Oecologia 151:431-441.

Heidorn, T. J., and A. Joern. 1987. Feeding preference and spatial distribution by grasshoppers (Acrididae) in response to nitrogen fertilization of Calamovilfa longifolia. Functional Ecology 1:369-375.

Joern, A. 1979. Feeding patterns in grasshoppers (Orthoptera: Acrididae): factors influencing diet specialization. Oecologia 38:325-347.

Joern, A. 1985. Grasshopper dietary (Orthoptera: Acrididae) from a Nebraska sandhills prairie. Transactions of the Nebraska Academy of Sciences 13:21-32.

Joern, A. 2004. Variation in grasshopper (Acrididae) densities in response to fire frequency and bison grazing in tallgrass prairie. Environmental Entomology 33:1617-1625.

Joern, A. 2005. Disturbance by fire frequency and bison grazing modulate grasshopper species assemblages (Orthoptera) in tallgrass prairie. Ecology 86:861-873.

Joern, A., and S. B. Gaines. 1990. Population dynamics and regulation in grasshoppers. Pages 415-482 in R. F. Chapman and A. Joern, editors. Biology of grasshoppers. John Wiley and Sons, New York, New York, USA.

Johnson, J. B., and K. S. Omland. 2004. Model selection in ecology and evolution. Trends in Ecology and Evolution 19:101-108.

Jonas, J. L., and A. Joern. 2007. Grasshopper (Orthoptera: Acrididae) communities respond to fire, bison grazing and weather in North American tallgrass prairie: a long-term study. Oecologia 153:699-711.

Jonas, J. L., and A. Joern. 2008. Host plant quality alters grass: forb consumption by a mixed-feeding herbivore, Melanoplus bivitattus. Ecological Entomology 33:546-554.

Kakie, T. 1969. Phosphorus fractions in tobacco plants as affected by phosphate application. Soil Science and Plant Nutrition (Tokyo) 15:81-85.

Kaspari, M., and S. P. Yanoviak. 2009. Biogeochemistry and the structure of tropical brown food webs. Ecology 90:33423351.

Kaspari, M., S. P. Yanoviak, R. Dudley, M. Yuan, and N. A. Clay. 2009. Sodium shortage as a constraint on the carbon cycle in an inland tropical rainforest. Proceedings of the National Academy of Sciences USA 106:19405-19409.

Kay, A. D., S. E. Scott, J. D. Schade, and S. E. Hobbie. 2004. Stoichiometric relations in an ant-treehopper mutualism. Ecology Letters 7:1024-1028.

Loaiza, V., J. L. Jonas, and A. Joern. 2011. Grasshoppers (Orthoptera: Acrididae) select vegetation patches in localscale responses to foliar nitrogen but not phosphorus in native grassland. Insect Science 18:533-540.

Lockwood, J. A. 1997. Grasshopper population dynamics: a prairie perspective. Pages 103-128 in S. K. Gangwere, M. C. Muralirangan, and M. Muralirangan, editors. The bionomics of grasshoppers, katydids and their kin. CAB International, New York, New York, USA.

Marschner, H. 1995. Mineral nutrition of higher plants. Second edition. Academic Press, San Diego, California, USA.

Mattson, W. J., and R. A. Haack. 1987. The role of drought in outbreaks of plant-eating insects. BioScience 37:110118.

McCune, B., and J. B. Grace. 2002. Analysis of ecological communities. MJM Software Design, Gleneden Beach, Oregon, USA.
McCune, B., and M. J. Mefford. 1999. PC-ORD. Multivariate analysis of ecological data. MJM Software Design, Corvallis, Oregon, USA.

Mills, H. A., and J. B. Jones, Jr. 1996. Plant analysis handbook II. A practical sampling, preparation, analysis, and interpretation guide. Micromacro, Athens, Georgia, USA.

Moe, S. J., R. S. Stelzer, M. R. Forman, W. S. Harpole, T. Daufresne, and T. Yoshida. 2005. Recent advances in ecological stoichiometry: insights for population and community ecology. Oikos 109:29-39.

Molleman, F. 2010. Puddling: from natural history to understanding how it affects fitness. Entomologia Experimentalis et Applicata 134:107-113.

O'Neill, K. M., B. E. Olson, M. G. Rolston, R. Wallander, D. P. Larson, and C. E. Seibert. 2003. Effects of livestock grazing on rangeland grasshopper (Orthoptera: Acrididae) abundance. Agriculture, Ecosystems and Environment 97:51-64.

Onsager, J. A. 1977. Comparison of five methods for estimating density of rangeland grasshoppers. Journal of Economic Entomology 70:187-190.

Perkins, M. C., H. A. Woods, J. F. Harrison, and J. J. Elser. 2004. Dietary phosphorus affects the growth of larval Manduca sexta. Archives of Insect Biochemistry and Physiology 55:153-168.

Pitt, W. C. 1999. Effects of multiple vertebrate predators on grasshopper habitat selection: trade-offs due to predation risk, foraging and thermoregulation. Evolutionary Ecology 13:499-515.

Raubenheimer, D., and S. J. Simpson. 1993. The geometry of compensatory feeding in the locust. Animal Behaviour 45:953-964.

Raubenheimer, D., S. J. Simpson, and D. Mayntz. 2009. Nutrition, ecology and nutritional ecology: toward an integrated framework. Functional Ecology 23:4-16.

Rosenthal, G. A., and M. R. Berenbaum, editors. 1992. Herbivores: their interactions with secondary plant metabolites. Second edition. Academic Press, New York, New York, USA.

Schade, J. D., M. Kyle, S. E. Hobbie, W. F. Fagan, and J. J. Elser. 2003. Stoichiometric tracking of soil nutrients by a desert insect herbivore. Ecology Letters 6:96-101.

Schmitz, O. J. 2009. Effects of predator functional diversity on grassland ecosystem function. Ecology 90:2339-2345.

Schmitz, O. J., A. P. Beckerman, and K. M. O'Brien. 1997. Behaviorally mediated trophic cascades: effects of predation risk on food web interactions. Ecology 78:1388-1399.

Schoonhoven, L. M., J. J. A. van Loon, and M. Dicke. 2005. Insect-plant biology. Oxford University Press, Oxford, UK.

Simpson, S. J., and D. Raubenheimer. 2001. The geometric analysis of nutrient-allelochemical interactions: a case study using locusts. Ecology 82:422-439.

Simpson, S. J., G. A. Sword, P. D. Lorch, and I. D. Couzin. 2006. Cannibal crickets on a forced march for protein and salt. Proceedings of the National Academy of Sciences USA 103:4152-4156.

Smedley, S. R., and T. Eisner. 1995. Sodium uptake by puddling in a moth. Science 270:1816-1818.

Sterner, R. W., and J. J. Elser. 2002. Ecological stoichiometry: the biology of elements from molecules to the biosphere. Princeton University Press, Princeton, New Jersey, USA.

Trumper, S., and S. J. Simpson. 1993. Regulation of salt intake by nymphs of Locusta migratoria. Journal of Insect Physiology 39:857-864.

White, T. C. R. 1993. The inadequate environment: nitrogen and the abundance of animals. Springer-Verlag, Berlin, Germany.

White, T. C. R. 2008. The role of food, weather and climate in limiting the abundance of animals. Biological Review 83:227248. 
With, K. A., and T. O. Crist. 1995. Critical thresholds in species' responses to landscape structure. Ecology 76:24462459.
Woods, H. A., M. C. Perkins, J. J. Elser, and J. F. Harrison. 2002. Absorption and storage of phosphorus by larval Manduca sexta. Journal of Insect Physiology 48:555-564.

\section{Supplemental Material}

\section{Appendix A}

Relative abundances of grasshopper species at each site and overall relative abundance of each species averaged over all sites (Ecological Archives E093-087-A1).

\section{Appendix B}

Relative abundances and densities of grasshopper feeding guilds by sites (Ecological Archives E093-087-A2).

\section{Appendix C}

Analytical methods used in the elemental analyses of plant tissue (Ecological Archives E093-087-A3).

\section{Appendix D}

Models compared in AIC analyses (Ecological Archives E093-087-A4). 